\title{
4
}

\section{What about Private Options?}

\author{
Jon D. Michaels
}

There is today considerable enthusiasm for public options, notably in the healthcare and banking sectors. A compromise between entirely private commercial provisions and wholly bureaucratic, tax-and-transfer government provisions, public options are designed to offer citizen-consumers greater choice and protection. In blending (rather than choosing between) market ordering and state welfare, government must cross over. Government officials must step out of their sovereign lane, forgoing legislative and regulatory tools in favor of commercial ones.

This is no small step. For the better part of a hundred years, government officials have done most of their work within the confines of the sovereign lane. That is to say, they have passed laws, promulgated rules, and imposed taxes to discipline markets and empower consumers, workers, and townspeople affected by various businesses and business transactions. Now, with public options, they are seeking to achieve substantially similar ends but through market participation: buying, selling, trading, and leasing, just like any commercial actor.

For example, public options in the health-care sector stand in for old-school regulation of private providers and old-school redistribution to better support those struggling to pay for private insurance and medical services. ${ }^{1}$ Public options in banking work substantially the same way. The government casts aside sovereign tools of democratic lawmaking, tools that may be used to require (or nudge) banks to accept customers deemed poor or risky. Instead, government officials set up and run public banks, offering a range of commercial services to "unbanked" and "underbanked" cohorts. ${ }^{2}$

1 See Ganesh Sitaraman \& Anne L. Alstott, The Public Option: How to Expand Freedom, Increase Opportunity, and Promote Equality 202-21 (2019); Jacob S. Hacker, Health Care for America, Econ. PoL'Y INST.(January 11, 2007), https://perma.cc/8B2A-MKL3.

2 See Jordan Weissman, Kirsten Gillibrand Unveils Her Ambitious Plan to Turn the Post Office into a Bank, Slate (April 25, 2018), https://perma.cc/VA2N-DH 9 B; see also Sitaraman \& Alstott, supra note 1, at 169-78; Mehrsa Baradaran, It's Time for Postal Banking, 127 Harv. L. Rev. Forum 165, 165 (2014), https://perma.cc/L7 $\mathrm{H}_{4}$-FALD; Seth Victor, Postal Banking and Government Profitability: When Should Government Have to Make Money?, 19 Conn. Pub. InT. L.J. 15 (2019). 
Public options represent a crossing over in one direction: from the sovereign to commercial. There is, to be sure, plenty of thoughtful work on public options, in this volume and elsewhere. ${ }^{3}$ For that reason, this essay turns its attention to the converse phenomenon - the emergence, or rather reemergence of private options.

Private options may seem like a gussied-up label for a familiar concept. That's partly true. Everyday examples of private self-help or private ordering certainly constitute alternatives to government provision. But here context really matters. Just as public options involve governments using commercial - not sovereign pathways to remedy market failures, private options involve firms (or groups of employees) adopting sovereign - not commercial - postures to remedy government failures.

Private, sovereign-like interventions refer to one or more of the following: (1) Firms (or subsets of firm stakeholders) use democratic pathways and deliberative procedures in furtherance of some public policy. In effect, they follow the laws of democracy rather than the laws of capitalism - namely, buying, selling, and trading pursuant to the demands and dictates of supply and demand. (2) Firms (or subsets of firm stakeholders) take on substantive responsibilities that modern liberal democracies have, by and large, consistently assigned to government actors. ${ }^{4}$ (3) Firms (or, once more, subsets of firm stakeholders) provide principally for the general welfare and they proceed in ways that suggest they may be, among other things, voluntarily internalizing externalities, at some profit loss or legal risk; or voluntarily reducing rather than exploiting power and information asymmetries.

These either democratically deliberative or paternalistically public-regarding activities may (but need not) stand in some, perhaps quite stark, tension with profitmaximization - the central and almost always overriding imperative of twenty- and early twenty-first century corporate law and political economy. ${ }^{5}$ That is to say, when it comes to private options, the eschewal of profits is neither a necessary nor sufficient condition.

Private options of a quasi-sovereign variety include such things as Facebook's proposed digital currency ${ }^{6}$ and its self-styled supreme court tasked with rendering

3 See, e.g., Sitaraman \& AlstotT, supra note 1.

4 Note that what I'm describing earlier - namely, firms taking on responsibilities traditionally handled by government actors - ought not be confused or conflated with government outsourcing. Government outsourcing, a pervasive practice, is not the same as deregulation or abdication. When government deregulates or abdicates responsibility, it may well be up to the private sector to fill the newly created void. By contrast, when the government outsources, it is still carrying out the assigned duties, albeit with the (often substantial) help of an alternative workforce. See Jon D. Michaels, We the Shareholders: Government Market Participation in the Postliberal U.S. Political Economy, 120 Colum. L. REV. 465, 525-28 (2020).

5 See, e.g., Michael C. Jensen, Value Maximization, Stakeholder Theory and the Corporate Objective Function, 12 Bus. EThics. Q. 235 (2002); Henry Hansmann \& Reinier Kraakman, The End of History for Corporate Law, 89 Geo. L. J. 439, 439 (2000).

6 See, e.g., Mike Isaac \& Nathaniel Popper, Facebook Plans Global Financial System Based on Cryptocurrency, N.Y. Times (June 18, 2019), https://perma.cc/66LQ-L3DW. 
adjudicatory decisions as to user and advertiser content. ${ }^{7}$ They also include Apple and Google's planned stewardship over what is in many respects the twenty-first century reboot of an old-school company town. ${ }^{8}$ We may even look beyond the C-suite and consider workforces as fashioning their own private options, quite possibly as commercial analogs to the body politic. Specifically, worker strikes and protests over their companies' participation in politically questionable government programs may likewise constitute private options. These workers are not taking steps to augment their own wages and benefits. To the contrary, they are risking their own financial security to stand in for the American electorate when that electorate is, for reasons of a structural government failure, unable to influence, say, US immigration or defense policy. ${ }^{9}$

This essay drills down on private options, starting what I hope becomes a broader conversation about private options, their defining characteristics, the timing of their (re)emergence, and their role within the larger ecosystem of government and market institutions and actors. Section 4.1 begins by discussing how public and private options represent major challenges to modern legal liberalism. Whereas modern legal liberalism has been marked by the separation of state and private power - and specialization within each sector- today we see not only a blurring of public and private identities but also a commingling of sovereign and commercial responsibilities. Section 4.2 incorporates the concept of government failure, noting reasons why and circumstances when the state is unable to govern legitimately or effectively, if at all. Section 4.3 then explains why firms may be especially well positioned today to take on various quasi-sovereign projects, (for better or worse) filling gaps left by stymied state officials unable or unwilling to overcome one or more government failures. Section 4.4 offers illustrations of private options, each corresponding to specific government failures. Section 4.5 concludes by teeing up some of the normative and legal considerations that demand our attention going forward. ${ }^{10}$

\subsection{FROM LEGAL LIBERALISM TO PUBLIC CAPITALISM}

Public and private options constitute new and challenging efforts to blur, erase, or transcend one of the most resonant and relevant dividing lines of twentieth-century American law and political economy. It was, after all, the advent of modern legal liberalism that brought with it, first, the separation of state and private power, understood principally in terms of state efforts to protect and respect private ordering

7 See Tony Romm, Facebook Unveils Charter for Its 'Supreme Court,' Where Users Can Go to Contest the Company's Decisions, WASH. Post (September 17, 2019), https://perma.cc/X2AT-TXD5.

8 See Ashlee Vance, Google and Mountain View Recast Company-Town Model, N.Y. Times (February 18, 2010), https://perma.cc/E9SW-U $\mathrm{U}_{3} \mathrm{G}_{4}$.

9 See infra Section IV.D.

10 Indeed, constraints of space and scope prevent me from delving more deeply into what it means for companies to wield private yet quasi-sovereign power. For present purposes, I merely note the need for greater scrutiny of the sort I intend to apply in subsequent projects. 
in commercial, civic, religious, and social affairs; second, the specialization and compartmentalization of state and private power, such that each sector advanced different agendas, used different procedures and tools, was held accountable by different legal and moral standards, and was answerable to different constituencies; and, third, competition between state and private actors to determine whether a given policy domain ought to be subject to greater or lesser government-imposed redistribution and regulation. ${ }^{11}$

At the risk of oversimplification, in the modern American political economy federal, state, and local governments lessened their often routine and haphazard commercial forms of engagement, privatizing some functions and converting others into more decidedly noncommercial programs - that is, bureaucratic, coercive, and generally redistributive. ${ }^{12}$ And firms, which in premodern times were known to be (and expected to be) somewhat if not manifestly paternalistic and public-regarding, ${ }^{13}$ started focusing exclusively on profit-maximization, thus leaving little space or opportunity to engage in anything akin to quasi-sovereign projects. $^{14}$

Public options constitute an alternative, a third-way mashup of modern legal liberalism's binary choice between state sovereign (regulation and redistribution) programs and private commercial offerings. Instead of choosing either state regulation or private ordering, policymakers split the difference. That is to say, government advances its sundry aims and commitments using commercial, rather than sovereign, tools and pathways. The same is substantially true for firms as they reach into the state's trusty toolbox to appropriate some sovereign tools. Elsewhere I call this bidirectional, twenty-first century postliberal mashup public capitalism. ${ }^{15}$

Under public capitalism, public and private identities matter less than sovereign and commercial postures. This is because both state and private actors are each taking on sovereign and commercial projects, each utilizing sovereign and commercial

1 For a fuller description, see Michaels, We the Shareholders, supra note 4, at 472-75.

12 See, e.g., Joseph L. Weiner, The New Deal and the Corporation, 19 U. ChI. L. Rev. 724, 727-30 (1952); James Q, Whitman, Of Corporatism, Fascism, and the First New Deal, 39 Aм. J. Comp. L. 747 (1991).

13 Citizens United v. FEC, $55^{8}$ U.S. 310, 427 (2010) (Stevens, J., dissenting) ("Corporations were [originally] created, supervised, and conceptualized as quasi-public entities, 'designed to serve a social function for the state.") (internal citation omitted); Kent Greenfield, Ultra Vires Lives! A Stakeholder Analysis of Corporate Illegality (with Notes on How Corporate Law Could Reinforce International Law Norms), 87 VA. L. REV. 1279, 1303 (2001) ("The nineteenth century conception of the [corporation], as a historical matter, included a much stronger nod toward the public purpose of the firm than does the modern view.").

14 See Hansmann \& Kraakman, supra note 5; Jensen, supra note 5. Note, however, that firms have long been permitted to devote a "reasonable amount of resources to public welfare, humanitarian, educational, and philanthropic purposes." Principles of Corporate Governance, American Law Inst. $\int 2.01$ (October 2019); see also Jonathan R. Macey, A Close Read of an Excellent Commentary on Dodge v. Ford, 3 VA. L. \& Bus. Rev. 177, 178-79 (2008)(characterizing the quoted language as a "minor exception[] to the shareholder wealth maximization norm" that ensures "corporations be given sufficient latitude to act like responsible community members").

15 Michaels, We the Shareholders, supra note 4, at 503-22. 
pathways, and each toggling between the two sets of projects and pathways as circumstances and opportunities so dictate.

Showing the robustness of this public capitalism moment in one direction is relatively easy. Public options and many other forms of government market participation are clearly on the rise. ${ }^{16}$ But we haven't, as yet, paid as close attention to movement in the other direction - wherein private (and heretofore entirely commercial) actors take on sovereign roles and duties, principally to address one or more government shortcomings or outright failures.

\subsection{GOVERNMENT FAILURES}

Generally speaking, government interventions via regulation and redistribution are (and have long been) justified as responses to one or more so-called market failures, such as unequal bargaining power, unequal information, externalities, and public goods. ${ }^{17}$ We know and talk a lot about market failures. But as much as we study - and complain about - government, rarely are we called upon to ponder, let alone enumerate, an analogous set of government failures that, among other things, may help us better apprehend and analyze private options. With that in mind, consider the following categories of government failure.

Constitutional failures. The US Constitution does not provide government officials with all the tools they may need to advance policies supported by even rather sizable political majorities. Some of this is by design, as evidenced by the constitutional drafters' preferences for limited government. And some of this may be attributable to the inevitable shortsightedness of the framers who set forth a governing blueprint at a very different cultural, political, technological, economic, and geostrategic moment. Reasonable minds might disagree about how best to regulate hate speech and gun ownership. But the Constitution - or at least Supreme Court jurisprudence - renders many of those debates academic. Similar to when we're confronted with market failures that firms are unable or unwilling to address on their own, we as a community may countenance various constitutional failures, try to address them directly (through, say, constitutional amendments or judicial appointments), or look to nongovernmental actors to devise compensatory or ameliorative countermeasures.

Policy Failures. Sounding in a slightly different register are government policy failures. One may be hard pressed to find a rational basis for disputing the need to take at least modest steps to address climate change, to assure the existence of affordable housing, and to improve our public infrastructure. Yet very few, if any, legislative initiatives are forthcoming. Part of the explanation may connect to other government failures namely, jurisdictional failures, constitutional (that is, powers-of-Congress) failures,

16 See, e.g., id., at $490-500$.

17 See, e.g., Stephen Breyer, Regulation and Its Reform 15-34 (1982). 
and democratic failures. But perhaps just as likely, the reason we don't address climate change, the affordable housing crisis, or our dangerously outdated physical infrastructure is that we have a selfish, present-minded polity. That is to say, there may be instances when there are no other government failures impeding efforts to reduce carbon emissions, increase the housing stock, and upgrade crumbling bridges and roads. In those instances, what we have are otherwise unencumbered majorities simply unwilling to invest in their communities, presumably because the costs will be borne by present-day voters while the benefits accrue substantially, if not exclusively, to future generations. When and where we are confronted with policy failures of this sort, there may be a need for alternative collective enterprises, outside of the state, to step up and safeguard our shared future.

Jurisdictional failures. This government failure is perhaps the closest analog to the externalities concern commonly encountered in the marketplace. Notwithstanding its numerous historic and enduring virtues, the Westphalian system organized around powerful nation-states limits our ability to address any number of contemporary public policy challenges that transcend national borders. Environmental policy stands out, given the diffuse causes and effects of climate change. But financial, counterterrorism, public health, trade, migration, and labor policies are likewise of transnational significance. For national governments to effectively regulate beyond their borders, they need either to take Herculean steps to construct transnational regulatory regimes or to internalize the costs that, say, domestic pollution has on the world at large - and regulate accordingly. In either case, nation-states must act contrary to their own immediate selfinterest and do so knowing they may not succeed. Hence, as with constitutional failures, there may be reason to look to nongovernmental actors, including multinational firms, as possibly better positioned to address transnational externalities.

Democratic failures. To speak of a democratic failure presupposes one has in mind a certain normative understanding of healthy politics. But assuming, as I do, that there is some consensus around democratic politics that includes a baseline commitment to one-person, one-vote, ${ }^{18}$ then it is safe to say that the United States has an impoverished, structurally unequal system for collective self-governance. Among other things, the US Senate ranks among the least democratic legislative bodies in the world. ${ }^{19}$ And then there is our presidential election system, mediated (and distorted) by federalism and the Electoral College. ${ }^{20}$ Recall the last two Republican presidents - George W. Bush and Donald Trump - each won the White House while losing the popular vote, the latter

18 See, e.g., Stephen Ansolabehere \& James M. Snyder, JR., The End of Inequality: One Person, One Vote and the Transformation of American Politics (2008).

19 Alfred C. Stepan, Federalism and Democracy: Beyond the U.S. Model, 10 J. Dem. 19 (1999); Todd N. Tucker, Fixing the Senate: Equitable and Full Representation for the 21st Century, Roosevelt InsT., at 6 (March 2019), https://perma.cc/838K-WHXD. Given demographic and mobility trends, the Senate is apt to become even more undemocratic with each passing year. Id at 8 .

20 See, e.g., Sanford Levinson, Our Undemocratic Constitution 87-97 (2006). 
by nearly $3,000,000$ votes in 2016. In light of these patterns of democratic failure, often reinforced by constitutionally protected campaign finance practices that privilege plutocracy, by gerrymandering schemes, and by voter suppression efforts, ${ }^{21}$ one might expect, and even desire, the engendering of alternative venues for self-governance locales where it is conceivable that a different, more democratic version of politics may play out.

\subsection{FIRMS AS QUASI-SOVEREIGNS}

Government is the go-to venue for addressing market failures. Can, and should, the market return the favor by helping to overcome or compensate for various government failures? Given how singularly focused firms (and groups of employees) have been on profit maximization throughout the modern era, it may seem far-fetched to assume the market will do much more than exploit most government failures. A typical commercial response to the government's failure to regulate guns (because of the Court's Second Amendment jurisprudence) would be to undertake various self-help measures. Firms might, predictably, increase security at worksites, thereby more fully insulating employees, executives, and customers from the potential dangers associated with this particular government failure - but do little to safeguard the rest of the community. Some especially entrepreneurial firms might develop and sell new security services or goods, such as bulletproof vests and backpacks. ${ }^{22}$ But that's as far as many firms will be apt to go. After all, firms have limited resources and may be loath to expend funds in furtherance of public-regarding, nonremunerative outcomes that would also be of considerable benefit to rival businesses and their customers. That is, after all, why they pay taxes.

Yet notwithstanding understandable, intuitive grounds for skepticism, there are several reasons why market actors might be well positioned, today at least, to counteract or compensate for government failures - and to do so in an ostensibly public-regarding fashion, as if they were quasi-sovereigns themselves. Due to a convergence of novel conditions and circumstances, firms have the financial wherewithal, the clout, the maneuverability, and quite possibly the will (if not always the best of intentions) to stand in for the government. And, the public, for its part, may be sufficiently disillusioned with the promises and practices of legal liberalism to be receptive to private interventions of a quasi-sovereign sort.

In this subsection, I first address corporate capacity for, and interest in, taking on quasi-sovereign projects. I then turn to consider why, at this particular moment, the public may be amenable to firms taking on these projects.

${ }^{21}$ Rucho v. Common Cause, 139 S. Ct. 2484, 2509 (2019) (Kagan, J., dissenting); Citizens United, 558 U.S. at 427 (Stevens, J., dissenting); Gilda R. Daniels, Uncounted: The Crisis of Voter Suppression in America (2020); Lawrence Lessig, Republic, Lost: How Money Corrupts Congress - And a Plan to Stop It (2011); Nicholas Stephanopoulos, The Anti-Carolene Court, 2020 Sup. Ct. Rev. (forthcoming), https://papers.ssm.com/sol3/papers.cfm?abstract_id=3483321.

22 Sadly, such products exist. See, e.g., David Yaffe-Bellany, Bulletproof Backpacks in Demand for Backto-School Shopping, N.Y. Times (August 6, 2019), https://perma.cc/Z33 G4-DU8Q. 


\subsubsection{Corporate Capacity}

Bigness. A handful of firms today are so large and influential that they wield significant power over markets, consumers, and even governments. The size and dominance of these companies are leading some to characterize the instant moment as a second Gilded Age. ${ }^{23}$ The first such age coincided with the rise of industrial capitalism in the late-nineteenth century, the concentration of market power, the leveraging of that market power for political gain, and the engendering of great wealth and income inequality. ${ }^{24}$

We're seeing similar patterns at play today, with the chief differences being, first, that instead of industrial capitalism we're in a moment of high-tech capitalism; and, second, that the reemergence of a gilded political economy is especially problematic given the range of regulatory and redistributive laws and regulations instituted in response to the first Gilded Age. Yet here we are. Currently, the richest 400 Americans combine to own more of the nation's wealth than do the 150 million Americans constituting the bottom 60 percent. Since the 1980 , the richest 400 have tripled their share of the nation's wealth, generating levels of inequality and wealth concentration "last seen during the Roaring Twenties." ${ }^{25}$ (To put things in even starker perspective, three men - Bill Gates, Jeff Bezos, and Warren Buffett - combine to possess more wealth than the bottom 50 percent of the US population. ${ }^{26}$ ) Even within the rarefied world of the Standard \& Poor's 500, we see tremendous inequality. In 2015 , the top 28 firms generated more profits than did the other $472 .{ }^{27}$ And, more recently, in 2019, Apple and Microsoft alone accounted for 15 percent of the S\&P's aggregate gains, with Amazon, Facebook, and Alphabet/Google rounding out the top five firms. ${ }^{28}$

Firms dominating the instant Gilded Age constrain customer choice, inflate prices, and cause us to worry about morally hazardous behavior and systemic shocks, at least to the extent these entities are understood to be too big to fail. The "too big to fail" label took on special salience a decade ago in the wake of the global financial crisis. At that time, "too big to fail" referred principally to financial services firms. ${ }^{29}$ But we'd be hard pressed today to say that we're any less reliant on the likes of

23 Jack M. Balkin, The First Amendment in the Second Gilded Age, 66 Buff. L. Rev. 979 (2018) ("We are now well into America's Second Gilded Age.").

24 Richard White, The Republic for which It Stands: The United States during Reconstruction AND THE Gilded Age, 1865-1896 (2017).

25 Christopher Ingraham, Wealth concentration returning to 'levels last seen during the Roaring Twenties,' according to new research, WASH. POST (February 8, 2019), https://perma.cc/YH $58-$ UDG $_{7}$ (quoting UC-Berkeley economist Gabriel Zucman).

26 Sophie Smith, Bill Gates, Jeff Bezos and Warren Buffett Own More Wealth than the Poorest Half of the US, Telegraph (UK) (November 9, 2017), https://perma.cc/BYS6-TB85.

27 Matt Krantz, 6\% of Companies Make $50 \%$ of U.S. Profit, USA TODAY (March 2, 2016), https://perma .cc/ $4663-\mathrm{DL} 6 \mathrm{H}$.

28 Yun Li, The Five Biggest Stocks are Dwarfing the Rest of the Stock Market at an "Unprecedented" Level, CNBC (January 13, 2020), https://perma.cc/QXY7-89NK.

29 Andrew Ross Sorkin, Too Big to Fail: The Inside Story of How Wall Street and Washington Fought to Save the Financial System-and Themselves (2009). 
Google, Facebook, Apple, and Amazon, given those firms' role in facilitating our (and everyone else's) social, cultural, economic, and political exchanges. Simply put, disruptions in high-tech services would prove catastrophic. ${ }^{30}$

What I just described is the conventional doom-and-gloom story. But there are less carefully attended to and more complicated consequences of oligarchical firms reaping supernormal profits. For better or worse, these firms have the market share and financial cushion to stray a bit outside of their traditional lane of commercial engagement - a lane whose boundaries have been enforced by the prevailing and largely unquestioned legal norms and professional mores of twentieth-century corporate governance and industrial competition.

Before the emergence of modern liberal political economies, firms weren't so cabined both by a robust regulatory state and by legally empowered shareholders. Indeed, early American corporate charters placed special emphasis on the public-regarding purposes of corporations, ${ }^{31}$ a seemingly reasonable imposition on firms receiving the special legal benefits (and limited liabilities) of corporate personhood. Back then, we witnessed big, powerful firms acting with quasi-sovereign intent and taking on quasi-sovereign projects, including the governing of de facto company towns. ${ }^{32}$

In the modern era, many of these premodern colossi lost market share as a result of changing economic patterns, were broken up by antitrust authorities, or were penned into their commercial, profit-maximizing lane by courts, regulatory agencies, and shareholders. Modern legal and professional duties and obligations narrowed the scope of firms' ambitions - and limited their ability to commit resources to quasistatist projects. Now, however, the size and market dominance of leading tech firms take us back to those days before we had a fully modernized political economy. It thus may stand to reason that today's giant firms have greater power and flexibility to reengage in quasi-sovereign projects, including ones that address government failures.

CEO-Owners. Another key feature of quite a few of today's mega firms is a special leadership dynamic, again at least in many respects unlike what we've experienced since the tail-end of the first Gilded Age. The leaders of today - like the old-school steel, coal, oil, and banking magnates - are not professional corporate managers with

30 See Rana Foroohar, Don’t Be Evil: How Big Tech Betrayed Its Founding Principles - and All of Us (2019); James Titcomb, Tech Giants Have Become the New "Too Big to Fail," TelegraPh (UK) (November 25, 2019), https://perma.cc/5PMH-8LMW.

$31 \quad$ See supra note 13 and accompanying text.

32 See Quentin R. Skrabec, JR., Benevolent Barons: American Worker-Centered Industrialists, 1850-1910, at 53-56 (2011) (describing Lowell mill town as a company town that aimed to meet employees' housing, educational, cultural, and spiritual needs - and did so in a way that purported to promote healthy and wholesome living); see also Linda Carlson, Company Towns of the Pacific Northwest 36-40 (2017); Richard M. Candee, New Towns of the Early New England Textile Industry, 1 Persp. in Vernacular Arch. 31, 31-36 (1982); Rickey Hendricks, Medical Practice Embattled: Kaiser Permanente, the American Medical Association, and Henry J. Kaiser on the West Coast, 1945-1955, 60 Pac. Hist. Rev. 439, 440 (1991); Diana Davids Hinton, Creating Company Culture: Oil Company Camps in the Southwest, 1920-1960, 11 Sw. HIST. Q. 369, 375 (2008). 
limited equity. Even the most charismatic and influential among that modern corporate-manager cohort - think Lee Iacocca, Jack Welch, or Michael Eisnercould do little that strayed beyond the profit-maximization directive. So while there was the occasional Sam Walton, Oprah Winfrey, or Ted Turner, who created, controlled, and ran vast companies, most corporate heads in modern times have been glorified employees and acted as such. Today's Zuckerberg, Bezos, Musk, Brin, and Page are throwbacks to the age when larger-than-life corporate heads were also the principal founder-owners. They accordingly possess greater legal freedom, institutional authority, and cultural capital to push projects potentially orthogonal to the pursuit of profits. And each of these latter-day founder-owners has expressed interest in, and demonstrated some commitment to, doing precisely that. 33

Corporate Social Responsibility (CSR). Businesses today are well aware of the growing importance and heightened political salience of CSR. Throughout the modern era of legal liberalism, the legally and culturally instantiated profit-maximization imperative left little opportunity for advancing the interests of anyone other than shareholders. But over the past decade or so, American corporations have become more attentive, in word $^{34}$ if not (yet?) in deed ${ }^{35}$ to the interests of customers, employees, business partners, and community members alike. For instance, the Business Roundtable, a prominent umbrella organization comprising the CEOs of leading American corporations, recently took a dramatic step to redefine the corporation. The Roundtable committed to de-emphasizing profits and, in keeping with that commitment, announced that "Americans deserve an economy that allows each person to succeed through hard work and creativity and to lead a life of meaning and dignity." 36 This recognition that firms need to, once again, attend to broader sets of stakeholders may be nothing more than disingenuous virtue-signaling. ${ }^{37}$ But if there is any substance to the Roundtable's "redefin[ing] the purpose of a corporation," then we may well see some of America's most powerful firms taking it upon themselves to address one or more government failures. $^{3^{8}}$

33 Conor Dougherty, Facebook Pledges \$1 Billion to Ease Housing Crisis Inflamed by Big Tech, N.Y. Times (October 22, 2019), https://perma.cc/3SZE-TMS 4; David McCabe and Karen Weise, Amazon Accelerates Efforts to Fight Climate Change, N.Y. Times (September 19, 2019), https://perma.cc /8MLQ-V6PW.

34 Rebecca M. Henderson, More and More CEOs Are Taking Their Social Responsibility Seriously, HARV. Bus. Rev. (February 12, 2018), https://perma.cc/LWV8-SSLC.

35 See Lucian A. Bebchuk \& Roberto Tallarita, The Illusory Promise of Stakeholder Governance (March 5, 2020), https://papers.ssrn.com/sol3/papers.cfm?abstract_id=3544978.

$3^{6}$ Jena McGregor, Group of Top CEOs Says Maximizing Shareholder Profits No Longer Can Be the Primary Goal of Corporations, Wash. Post (August 19, 2019), https://perma.cc/5UQ2-B9JQ; Business Roundtable, Statement on the Purpose of a Corporation (August 19, 2019), https://perma.cc/552DBGP9.

37 Bebchuk \& Tallarita, supra note 35 .

$3^{8}$ See, e.g., Energy Management: Balancing Climate, Cost, and Choice, Deloitte Resources 2019 Study, at 17 , https://perma.cc/6S 4 E-YHWN; Hugh MacArthur, et al., Investing with Impact: Today's ESG Mandate in Private Equity, Bain \& Co. 2020 Global Private Equity Report, https://perma.cc/T5PU-F759. 
Patriotic Philanthropy. Stymied in large part by an American electorate hostile to taxes, government officials are increasingly soliciting corporate patrons to sponsor any number of state programs or initiatives. They thus seek financial support for municipal education, national parks, public health research, and even governmentinitiated litigation..$^{39}$ This patriotic philanthropy, as it has come to be called, allows corporations to donate to specific government causes while claiming a tax deduction for the charitable giving. ${ }^{40}$ Given some of the donor-attached strings - witness Mark Zuckerberg's control over curriculum and personnel attendant to his \$100 million donation to the Newark, New Jersey schools ${ }^{41}$ - it is no longer such a big step for firms to take on big quasi-sovereign projects directly, bypassing government agencies as the proverbial (and, by many an entrepreneur's lights, woefully bureaucratized) middlemen.

\subsubsection{Public Receptivity}

Pervasive Blending of Public and Private. Though the public and private have never been hermetically sealed from one another, one of the attributes (if not unqualified accomplishments) of modern legal liberalism was the development of a sizable, robust, and professional public bureaucracy that could carry out practically all of the work of the state in a manner divorced from the push and pull of the marketplace. ${ }^{42}$ Yet despite this capacity, the government has, for the past several decades, strived to downplay the specialness of the state sector and to narrow the gap between the public and private spheres. ${ }^{43}$ To that end, government officials have deputized private actors to police neighborhoods, lead combat missions, analyze counterterrorism data, patrol borders, conduct environmental and occupational safety inspections, and adjudicate welfareeligibility disputes. ${ }^{44}$ This late twentieth and early twenty-first century blurring of the public-private boundary (and corresponding effort to run government like a business ${ }^{45}$ ) seemingly makes it easier today to accept various crossover interventions, both public options $^{46}$ and corporate-led projects of a quasi-sovereign variety.

Disillusionment with Modern Legal Liberalism. There is, currently, considerable frustration and distrust with both the state qua sovereign and firms qua commercial

39 See Michaels, We the Shareholders, supra note 4, at 498-99.

$4^{\circ}$ See Margaret H. Lemos \& Guy Uriel-Charles, Patriotic Philanthropy? Financing the State with Gifts to Government, 106 CaL. L. REV. 1129 (2018).

41 Dale Russakoff, The Prize: Who's in Charge of America's Schools (2015).

42 See Jon D. Michaels, Constitutional Coup: Privatization's Threat to the American Republic 39-50 (2017).

43 See Jon D. Michaels, Running Government as a Business ... Then and Now, 128 HaRv. L. Rev. 1152, 1159-67 (2015).

44 See Jon D. Michaels Privatization's Pretensions, 77 U. Chi. L. Rev. 717 (2010); Jon D. Michaels, Deputizing Homeland Security, 88 Tex. L. Rev. 1435 (2010).

45 See Michaels, Running Government, supra note 43.

$4^{6}$ Michaels, We the Shareholders, supra note 4, at 506-13. 
profit-maximizers. ${ }^{47}$ When one is no longer in the thralls of the state (as, say, champions of the New Deal and Great Society might have been), or in the thralls of the market (as, say, champions of the 196os Chicago School, Reaganomics, or even the Clinton/Gore "third way" might have been), it becomes easier to abandon the specialization, separation, and stylized competition we associate with legal liberalism. Beholden to neither archetype, disillusioned citizen-consumers would seemingly be more amenable to, even welcoming of, innovative crossover practices, both government market participation and firms acting as quasi-sovereigns. ${ }^{4}$

Transactional, Unbundled, One-Off Exchanges. For a variety of reasons, we're much more likely today to think of our various social and commercial relationships transactionally. Consider the popularity of Tinder - as compared to traditional courtship-driven dating; and Task Rabbit - as compared to forging relationships built on friendship and reciprocity with handy neighbors. Consider too many TV viewers' preference for various curated streaming services over all-inclusive cable packages. Lastly, note consumers' fondness for singular AirBnB flats, perfect for this particular trip (but perhaps never again), over cookie-cutter Marriotts and Hiltons. In these important spaces, our relationships have become more transactional, more unbundled, and more one-off and ad hoc (as opposed to long term and consistent). ${ }^{49}$

The same may also be true when it comes to our relationship with the state. Already, as a result both of the public's anti-tax sentiments and the government's efforts to give off a businesslike vibe, we may be increasingly thinking about our interactions with the state as if we're customers of discrete services, rather than citizens of the sum total of government benefits and obligations. These transactional, unbundled forms of engagement suggest less of a holistic, all-in relationship with any one entity and more of an individuated, modular relationship with any number of potential service providers. Thus it may be easy for us to query whether the US Postal Service is insufficiently commercially oriented, something President Trump brings up when arguing that the Postal Service should be charging the likes of Amazon a whole lot more. And it may be quite natural today to press Facebook and Twitter to act more custodially, and do more content regulation notwithstanding a potential loss of profits. In other words, the more we see the world as a series of one-off transactions, the more willing we may be to ask commercial firms to act, in any particular instance, more or less profit-maximizing and ask government units, similarly in any particular instance, to act more or less commercially. This too paves the way for encouraging and ultimately endorsing government agencies providing public options and firms stepping into the shoes of a sovereign.

47 See, e.g., Uri Friedman, Trust is Collapsing in American, ATLANTIC (January 21, 2018), https://perma.cc NXC3-BCRM; Matthew Harrington, Survey: People's Trust Has Declined in Business, Media, Government, and NGOs, Harv. Bus. Rev. (January 16, 2017), https:/perma.cc/TUT5-7L93; Matt Stevens, Falling Trust in Government Makes It Harder to Solve Problems, Americans Say, N.Y. Times (July 22, 2019), https://perma.cc/FFT9-HPHX.

$4^{8}$ See Michaels, We the Shareholders, supra note 4, at 513-15.

49 Id. at $518-19$. 


\subsection{PRIVATE OPTIONS}

Consider the following plucked-from-the-headlines examples of what I'm classifying as private options and note how they line up with the various government failures identified in Section 4.2. In this section, I describe a quartet of private options, pair them with specific genres of government failure, and explain how these private options present opportunities and challenges different from those we associate with either conventional sovereign government services or conventional commercial firm offerings. Left to the side, for present purposes, are discussions of the efficacy, constitutionality, and legitimacy of these (or any other) private options. Though I believe concern, if not alarm, is warranted, inquiries along those lines are beyond the scope of this introductory essay and must, instead, be taken up in subsequent projects.

\subsubsection{Governing Public Fora (Constitutional Failures)}

Social media sites are increasingly viewed as public or quasi-public fora. ${ }^{50}$ This ought not to be surprising given the fact that Facebook, Twitter, and, God help us, Instagram, host important political and civic announcements, conversations, and debates. ${ }^{51}$ They're where news is announced, made, discussed, reframed, endorsed, distorted (or falsified), and further disseminated..$^{2}$ These digital venues are, to be sure, a marked change from the physical spaces - city halls, high school auditoriums, and town squares - where prior generations gathered to educate one another, persuade one another, and participate in our various democratic and civic projects.

Today's digital public fora are real and empowering in ways that would astonish those who came of age fifty or a hundred years ago. But they're also incredibly fraught spaces full of scam artists, bigots, and the like. Hucksters and haters obviously predate the digital age. But old-timey grifters and saboteurs couldn't reach as far, penetrate as deeply, or operate as deceptively when they had to do their damage at the retail level, and without the benefit of near or total anonymity. As a result of the promises and dangers of the digital public fora - not to mention the First Amendment's limitations on government-imposed speech regulations - the giant tech firms that administer these spaces face consumer and political pressure

50 For some important judicial treatments, see Packingham v. North Carolina, 137 S. Ct. 1730, 1735 (2017); Knight First Am. Inst. v. Trump, 928 F. 3d 226 (2d Cir. 2019), Davison v. Randall, 912 F. 3d 666, 680-81 (4th Cir. 2019).

${ }^{51}$ See, e.g., Jeremy Shapiro, Trump Has Redefined Political Communication for the Whole World-and Soon Everyone Could Speak Like Him, Bus. Insider (October 20, 2018), https://perma.cc/R9H9-L4KZ; Antonio Garcia Martinez, How Alexandria Ocasio-Cortez Shapes a New Political Reality, WIRED (January 9, 2019), https://perma.cc/AL2V-T5CC.

52 Elisa Shearer, Social Media Outpaces Print Newspapers in the U.S. as a News Source, Pew ResEARCH CTr. (December 10, 2018), https://perma.cc/UK4Z-YUAX. 
to function as stewards, if not outright regulators. ${ }^{53}$ Acting as regulators might entail aggressively filtering out fraudulent, hurtful, and even gratuitously graphic or obscene content.

Some of the tech firms are beginning to step into the constitutional void. They're developing procedures that they insist will filter, refine, and enrich content. Facebook, for example, is convening what it calls a supreme court to judge content. Members of this "court" reportedly will be walled off from the firm's executives and vice versa - to insure against financial considerations distorting the adjudicative process. Twitter, for its part, has banned all paid political content, "including appeals for votes, solicitations of financial support, and advocacy for or against" a wide range of matters relating to elections and public policy; it has also blocked PACs, SuperPACs, and 501(c)(4)s from advertising on its platform. ${ }^{54}$ Brad Parscale, President Trump's reelection campaign manager, criticized Twitter's decision, arguing that "Twitter just walked away from hundreds of millions of dollars of potential revenue, a very dumb decision for their stockholders." 55 In response, Twitter's CEO simply underscored his discomfort with the role money plays in influencing political outcomes and expressed his belief that "political message reach should be earned, not bought." ${ }^{6} 6$

One may certainly quibble with the procedures Facebook's court employs, and question whether the court can ever be truly independent from the Menlo Park bean counters. One may, likewise, criticize Twitter's policy and question how consistently and effectively it'll be applied in practice. But given Facebook and Twitter's importance to public discourse, it is difficult to deny that these media giants are acting as quasi-sovereigns, regulating access to effectively public fora, deciding what is and isn't objectionable, protecting (we hope) the integrity of elections, and helping restore confidence and encourage more participation in the democratic process (and doing so in part by making clear they're acting orthogonally to, if not squarely against, their commercial interests). ${ }^{57}$

When big tech firms regulate their platforms, the intent and effect is very different from, say, a bowling alley policing its clientele's speech or conduct. The owners of 300 Bowl have a lot of governing to do. They need to ensure everyone's health and safety, not a small feat given their high-volume shoe rental business and the potentially tumultuous admixture of free-flowing brews and fast-throwing twelvepound balls. And they may decide that they have to regulate what may be said at, say, Open-Mic Fridays in the bowlers' lounge. How 300 Bowl governs itself matters, but

53 Kate Klonick, The New Governors: The People, Rules, and Processes Governing Online Speech, 131 HaRv. L. Rev. 1598 (2017).

54 TwitTer, https://perma.cc/N6JX-KULN (last visited March 25, 2020).

55 Kendall Karson \& MattZarnell, Twitter Outlines Sweeping Details of Ban on Political Ads, ABC NEws (November 15, 2019), https://perma.cc/9TAD-WPY6. For what it is worth, it seems as if Twitter nets far less revenue from political ads than does Facebook and Google. See id.

${ }_{5} 6 \mathrm{Id}$

57 Cf. Nixon v. Shrink Missouri Government PAC, 528 U.S. 377, 401 (2000) (Breyer, J., concurring). 
in a way qualitatively different from how Facebook regulates its social media platform. We'd have to squint really hard to gauge the marginal effect 300 Bowl's open-mic policy has on our democracy or broader political economy. When it comes to Facebook or Twitter, the converse is decidedly true. Content regulation by the behemoths of social media affects the legitimacy of elections, the stability of our economy, and the sanctity of our civil rights and civil liberties. In all these respects, Twitter and Facebook might well be more impactful than many full-fledged sovereign states, quite a few of which find themselves at the mercy of social media platforms..$^{8}$

Thus, though there is not a sharp analytical distinction between a local bowling alley and a social media juggernaut each having governance rules about speech and debate, there are plenty of reasons to treat the two entities completely differently. Among them, first and foremost is a simple matter of scale. When it comes to tech giants, we cannot speak in terms of discrete groups of specially affected employees and customers. These firms have a global impact. Second is a question of third-party effects. If you never set foot in $300 \mathrm{Bowl}$, their house rules aren't going to affect your rights, liberty, or quality of life. And if you enjoy bowling but dislike zoo Bowl's rules, you can go for a short drive and find an alley more to your liking. By contrast, if you never log on to Facebook or Twitter, your life, livelihood, and even "IRL" conversations are nonetheless affected by what happens on those sites, simply because so many other people are dialed in and often socially, politically, and economically dependent on those sites. That is to say, going off the grid, or onto a different platform, is likely highly limiting, in a way switching bowling alleys would never be. Third is a question of the supremacy of law. 300 Bowl's house rules are entirely subordinate to local, state, and federal law. Questions of the primacy of public law vis-à-vis tech giants are more difficult to answer. Depending on how they incorporate, where they operate, and where they locate their servers, some tech firms may be able to evade any number of jurisdiction-sensitive laws. ${ }^{59}$

\subsubsection{Providing Social Services (Policy Failures)}

It is hardly a secret that there are major housing, transportation, and overall affordability crises in some of the nation's largest and most prominent cities and metropolitan areas, including those, such as Seattle and Silicon Valley, home to highly profitable and rapidly expanding tech businesses.

During the twentieth-century heyday of legal liberalism, periods of economic growth and contraction were managed principally through sovereign government interventions. State and local governments zoned aggressively, built additional infrastructure, and provided various tax or regulatory incentives to encourage or

$5^{8}$ See Anupam Chander, Facebookistan, 9o N.C. L. REv. 1807 (2012); Kristen E. Eichensehr, Digital Switzerlands, 167 PA. L. Rev. 665 (2019).

59 See Eichensehr, supra note 58. 
deter commercial expansion. That doesn't mean government officials always succeeded - but they generally tried (and were expected to try). Of late, however, public stewardship has been sorely lacking, no doubt a function of our political culture becoming fanatically anti-tax and more brazenly selfish - including but not limited to rising NIMBY activism.

So, in light of various government policy failures - meaning, again, the state's inability to address housing, transportation, or health-care shortfalls - some of the giant tech firms have undertaken self-help measures. Taking care of their own, they offset some of their employees' expenses and inconveniences. But housing stipends, transportation services, on-site medical, childcare, and gym facilities, and free or heavily subsidized meals are not substitutes for sovereign welfarist measures. They're in fact additional or alternative forms of compensation - and thus very much in keeping with a business-first commercial mindset. Indeed, if anything, many of these in-kind employee benefits actually exacerbate community crises. Employer-sponsored subsidies inflate the prices of local goods, housing, and services. What's more, because executives and employees of Google, Amazon, and Facebook have many of their needs and wants privately provided for, they are no longer motivated as citizens to clamor for greater public spending. Truth be told, unless they are especially other-regarding, these tech employees awash in in-kind benefits have reason to oppose additional public expenditures.

Now, however, tech giants face ever greater internal and external pressure to fix the damage their presence and policies have either caused or magnified - in part because government won't do so, at least not forcefully, through sovereign regulatory or tax-and-transfer programs. Absent wholesale government redistribution, wildly profitable and powerful firms may feel compelled to do far more than just subsidize their employees. To date, a few firms are beginning to respond. Three of the big tech companies - Apple, Microsoft, and Google - have committed to spending a combined $\$ 4$ billion to address the housing crises in the Bay Area and Seattle. ${ }^{6 \circ}$ Relatedly, Apple, Amazon, and Facebook are advancing incredibly ambitious and expensive planning initiatives, complete with mixed housing developments, retail offerings, brand-new municipal infrastructure, greenways, and parks that strike quite a few observers as points of entry for big tech firms to establish neo-company towns (over which the firms exercise substantial regulatory authority). ${ }^{61}$

6o Bill Chappell, Apple Pledges \$2.5 Billion To Combat California’s Housing Crisis, NPR (November 4, 2019), https://perma.cc/VL75-JKFE; Daisuke Wakabayashi \& Conor Dougherty, Google Pledges to Invest \$1 Billion to Ease Bay Area Housing Crisis, N.Y. TIMEs (June 18, 2019), https://perma.cc/TWC 7AKZC; Karen Weise, Microsoft Pledges \$5oo Million for Affordable Housing in Seattle Area, N.Y. Times (January 16, 2019), https://perma.cc/MU23-29B4.

61 David Streitfeld, Welcome to Zucktown. Where Everything Is Just Zucky, N. Y. Times (March 21, 2018), https://perma.cc/HUP3-R9XM; Leanna Garfield, Facebook and Amazon Are So Big They're Creating Their Own Company Towns - Here's the 200-year Evolution, Bus. Insider (March 26, 2018), https:// perma.cc/424R-8NGC. It's perhaps hard to dispute that classification when Google's "Mountain View and San Jose projects build on existing plans the cities had been working on for quite some time." 
To be clear, the differences between employee-targeted firm interventions and community-wide firm interventions are important. First, the employee-targeted interventions reify the sovereign/commercial distinction and likely engender greater socioeconomic inequality for the reasons stated earlier; the communitywide interventions, by contrast, blur the sovereign and commercial and have the potential to achieve greater communal inclusiveness - albeit on terms set by the firm.

Note too the differences between a private, quasi-sovereign Amazon or Google company town and, say, a city like Seattle or a county like Santa Clara that is willing and able to compel profitable firms, their owners, and their executives to pay their fair share of taxes into the public fisc. ${ }^{62}$ The neo-company town approach lowers firms' taxable income by reinvesting what would otherwise be taxable profits into quasi-public works projects - projects the firms direct and, once completed, largely manage. The conventional municipal town approach vests control over community welfare squarely in government institutions, underscoring the sovereign primacy of those public institutions and reinforcing the sovereign/commercial divide. Thus, in acting as a steward of a company town, the firm marginalizes the government by leaving public officials with fewer resources, opportunities, and reasons to make sovereign interventions. Community members will, for better or worse, have even greater need to look to leading firms for guidance, assistance, benevolence, or redress. $^{63}$

\subsubsection{Issuing Currency (Jurisdictional Failures)}

There are all sorts of inefficiencies baked into our global monetary system. Exchange rates between sovereign currencies fluctuate unpredictably, transaction costs are nonzero, and aggressive arbitraging by firms, investors, and speculators tends to disadvantage smaller, non-repeat players. ${ }^{6}$ What's more, competing sets of national banking regulations further complicate easy trading from one nation-state to another. As we become a more globalized, seamless economy through which

Ingrid Burrington, Who Gets to Live in Silicon Valley?, ATLANTIC (June 25, 2018), https://perma.cc 12 FQY-JMUV.

62 In drawing a comparison of this sort, some numbers from the Seattle area may be helpful. The entire Seattle Housing Authority's 2019 proposed annual budget was less than $\$ 300$ million, and the City of Seattle's 2019 proposed Office of Housing budget was less than $\$ 70$ million. Calendar Year 2019 SHA Proposed Annual Budget: Summary, Seattle Housing Authority (2018), https://perma.cc/YRN2-GANU ; City Budget Office: Online Budget, Housing, City of Seattle (2019), https://perma.cc/7ZBG-HQAY. The King County Housing Authority, which serves the communities surrounding Seattle, expends another \$300 million. See Overview, King County (Wash.) Housing Authority (last visited March 3, 2020), https://perma.cc/Q 7 F8-WWG9. By contrast, Microsoft alone has pledged \$500 million. See Weise, supra note 60.

63 See Burrington, supra note 61 .

64 See, e.g., Claus D. Zimmermann, The Concept of Monetary Sovereignty Revisited, 24 Eur. J. InT'L L. 797 (2013) (describing historical and enduring associations of state sovereignty with rights and duties associated with national currencies). 
labor, goods, and services flow freely across national borders, the sundry costs of bridging sovereign currencies may well undercut the expected, let alone full, benefits of free trade, weaken North-to-South lending initiatives, and dilute the impact of North-to-South remittances. ${ }^{65}$

These inefficiencies bespeak a jurisdictional failure. Of course, nations - and national governments - still matter. They still matter even though commerce crosses national boundaries with a speed, frequency, and insouciance that startle many a central banker. The European Union (EU) is obviously one major political undertaking that, among other things, helps minimize the jurisdictional mismatch between nation-states and economic communities. But even within Europe there are limitations - notably, between the EU and the rest of Europe, the United States, and Japan.

Private firms may quite naturally seek to overcome this particular, if inescapable, government failure. True to form, the first major effort in the twenty-first century to short-circuit nations' sovereign monopoly on currency has been a decidedly commercial one. Bitcoin presents itself as a commercial alternative to national currencies and exchanges. But Bitcoin has no trappings of sovereignty. There is no centralized governance, no body of overseers, managers, or guarantors. Instead, the cryptocurrency operates flatly, via permissionless blockchain that functions autonomously in a manner seemingly consistent with Adam Smith's “invisible hand." Bitcoin, moreover, is a speculative currency, not a transactional one that, again, depends on stewards to maintain stability.

But now a second-wave - this time, sovereign-seeming - private intervention is in the offing. To overcome the jurisdictional failure associated with national currencies, Facebook and a variety of partners are set to roll out a currency they call Libra. Libra is billed as a readily transferable form of digital exchange, purportedly superior to national currencies precisely because of its transnational fungibility. ${ }^{66}$ To this extent, Libra sounds a fair bit like Bitcoin. But Libra is provoking different, more worried responses. The French Finance Minister expressed concern that currencyissuing tech giants are "turning into private states - states over which citizens have no control and where democracy has no place." ${ }^{67}$ The minister's concerns seem more than justified. After all, Libra promises to be a centrally governed reserve currency.

65 Such concerns obviously predate the contemporary globalization era. See, e.g., J.S. MiLL, 2 PrinciPLES of Political ECONOMY 155 (1848) (remarking that "almost all independent countries choose to assert their nationality by having, to their own inconvenience and that of their neighbors, a peculiar currency of their own").

66 Libra White Paper, https://perma.cc/WSE8-9FJC; Olga Kharif, Why (Almost) Everybody Hates Facebook's Digital Coin, Wash. PosT (October 7, 2019), https://perma.cc/WC6D-4297; Carrie Mihalcik, Facebook's Libra May Look to Multiple Digital Coins Based on National Currencies, C| NET (October 21, 2019), https://perma.cc/T22E-79Q9; Andrew Morse, Here's What You Need to Know about Facebook's Controversial Libra Cryptocurrency, C|NET (October 24, 2019), https://perma.cc ${ }_{14} \mathrm{PJP}-\mathrm{XS} 6 \mathrm{D}$.

${ }_{67}$ Leigh Thomas, G7 Finance Ministers Look to Rein in Tech Giants at French Meeting, ReuTERS (July 17, 2019), https://perma.cc/QCJ9-CT2B. 
Facebook and its partners will fund the exchange, regulate how it is put into circulation, resolve disputes over how Libra is traded or redeemed, and stabilize its value in times of systemic shock. ${ }^{68}$ Libra also is bound to be a giant player from the outset, if for no other reason than it will readily sync up with Facebook's vast network of nearly two billion users and business partners scattered across more than one hundred nations. ${ }^{69}$ Thus not only is Libra poised to be on roughly equal footing with some of the world's major currencies - meaning that Facebook can, if it chooses, engage in serious macroeconomic statecraft - it is also well situated to displace some less-developed countries' currencies (as well as the sovereign reserve currencies those and other countries currently rely on).

\subsubsection{Workplace Governance (Democratic Failures)}

It isn't just corporate directors and managers who are adopting quasi-sovereign guises and standing in for state officials hamstrung by one or more government failures. It is also workers effectuating seemingly democratic projects within the corridors of their place of employment.

Consider some recent examples involving employees of Google and Wayfair, among others. In the case of Google, company engineers pushed corporate decisionmakers to stop doing business with US Customs and Border Protection, Immigration and Customs Enforcement, and the Office of Refugee Resettlement, at least so long as those departments advanced what the protesting employees deemed cruel and possibly unlawful initiatives. Among other things, the engineers alleged the feds were perpetrating "human rights abuses;" they criticized their firm's efforts to "support agencies engaged in caging and torturing vulnerable people;" and they insisted Google was "trading its integrity for a bit of profit." "7o (Microsoft and Amazon employees mounted similar intra-firm campaigns. ${ }^{71}$ ) On another occasion, Google employees successfully pressured management to walk away from another federal contract, fearing in this particular case that the AI technology it was furnishing would be used in combat situations. ${ }^{72}$

Way across the country, employees of Wayfair first signed a petition and then staged a highly publicized walkout in opposition to the Boston-based firm's arrangement to sell bedding to private detention centers housing migrant children separated from the rest of their families. The petition stated that Wayfair should take "no part

68 See Libra White Paper, supra note 66; Kharif, supra note 66; Mihalcik, supra note 66; Morse, supra note 66.

69 Kharif, supra note 66.

$7^{\circ}$ Cat Zakrzewski, The Technology 202: Googlers Demand Company Renounce Working with Trump Immigration Agencies, WaSH. Post (August 15, 2009), https://perma.cc/6W55-KV5E. For the actual protest letter, see No GCP for CBP, Google must stand against human rights abuses: \#NoGCPforCBP, Medium (August 14, 2019), https://perma.cc/H74F-YU 7 E.

${ }_{71}$ See Zakrzewski, supra note 70.

$7^{2}$ See id. 
in enabling, supporting, or profiting from" what the employees classified as malicious and unethical family separation policies and practices. ${ }^{73}$

What's going on here? Recall that modern legal liberalism enabled separation of the public from the private and specialization within each sphere. The public sphere democratized, incorporating and elevating the voices and projects of an inclusive polity. At the same time, the private sphere grew singularly focused on the maximization of shareholder profits. Social welfare was to be advanced through legislation, regulation, and, if necessary, adjudication. And the economy was to be strengthened through market competition and the laws of corporate governance.

Recall too that today's public levers are increasingly unresponsive. The great democratic revolution of the twentieth century is being rolled back, a result of hyperlibertarian campaign finance rulings, a lapsing commitment to voting rights (as voter suppression efforts target those on the racial or socioeconomic margins), and demographic dispersal patterns that invest some, often-unrepresentative constituencies with disproportionate voting power. In short, rising plutocracy coupled with the exacerbation of anti-democratic dynamics hardwired into the Constitution have made it harder for political majorities to influence public policy.

One way to deal with this current democratic failure is to overhaul the Constitution, passing amendments to overturn such cases as Citizens United. But that approach strikes many as daunting, if not hopeless. So instead of trying to make the seemingly corrupted public sphere more democratically responsive and thus public-regarding, some may seek an alternative approach. That approach may involve corrupting the private sphere by converting the corporate workplace into a democratic forum (at least when the real thing - that is, the conventional democratic forum - seems broken). Thus concerned citizens may not be able to use their voting power to stop the Trump administration's family separation policies. But maybe concerned workers - upon whom the government relies - can. ${ }^{74}$

Note the symmetry between employee-centered public policy initiatives and government market participation. In the latter cases, citizens see themselves in a business relationship with the government. And, here, in the former case, we have employees seeing themselves as part of a polity, relating to the firm first and foremost as concerned citizens, and raising policy objections orthogonal to, if not directly at odds with, their own financial well-being.

Employee-centered public policy initiatives of this sort appear to be in keeping with something that Kent Greenfield has been advancing for some years. Greenfield suggests that if a community cannot readily change a plutocratic political system, perhaps they ought to change corporate law. The employee protests at Google and Wayfair are attempts to get corporations to intervene in the political functioning of the state - not through voter drives or fundraising initiatives but rather by

73 Kate Taylor, Wayfair Furniture Employees Walked Out Over Sales to Migrant Facilities, N.Y. Times (June 25, 2019), https://perma.cc/A7MD-8GX9.

74 See id. Cf. Zakrzewski, supra note 70. 
withholding goods and services in a way that either embarrasses or disadvantages the government and perhaps forces the government to rethink their projects.

Employee protests, much like consumer boycott campaigns, may or may not work. Success seemingly depends on the political salience of the issue, the relative market power protesting employees possess, and the firm's market share. ${ }^{75}$ That's why Greenfield champions a set of changes far broader and less ad hoc than groups of workers acting the part of concerned citizens and hoping for the best. Specifically, he suggests corporate law be amended to define wealth maximization more broadly, prioritizing the maximization of value (and not necessarily monetary value) to all stakeholders, not just shareholders. Greenfield further advocates requiring corporations to include workers and other stakeholders on their boards, so that firms are better positioned to consider overall community welfare and, again, not just shareholder welfare. Last, he proposes compelling firms to extend their duty of care to workers and community members, too, such that firms have to take seriously ethical and practical objections to indisputably profitable business decisions. ${ }^{76}$

Many have painted reforms of this sort as aspirational rather than attainable perhaps just as quixotic as a constitutional amendment overturning Citizens United. But just a few years after Greenfield proffered these arguments, the Business Roundtable announced its newer, broader, and more inclusive understanding of corporations and their purpose. ${ }^{77}$ If Roundtable members commit to this revolutionary paradigm shift, firms may well stand in for government, particularly when state institutions are structurally unresponsive to the demands and needs of political majorities. ${ }^{78}$

\subsection{CONCLUSION}

We find ourselves in a moment when sovereign and commercial roles are in flux, as evidenced by, among other things, public and private options. With respect to

75 See Kent Greenfield, The Stakeholder Society, Democracy (Fall 2012), https://perma.cc/Z93S-SVA9. Palantir presents a countervailing case study. Palantir, more so than Google, Microsoft, or Wayfair, is dependent on the US government for steady work - and thus Palantir executives may be less inclined to back their employees when those employees object to certain government contracts. See Douglas MacMillan \& Elizabeth Dworkin, The War Inside Palantir: Data-mining Firm's Ties to ICE Under Attack by Employees, WASH. Post (August 22, 2019), https://perma.cc/AQ2T-YK8J.

76 See Greenfield, supra note 75.

77 See supra note 36 and accompanying text.

$7^{8}$ One might even consider the Trump Justice Department's efforts to use labor and employment law, seemingly to weaken the political independence of immigration judges, who have proven to be at least somewhat at odds with the political leadership's strident positions on immigration enforcement. Ordinarily, we might expect legislation or regulation to be the primary means by which the roles and responsibilities of government officials are defined and altered. But the Justice Department is also using market pressures - specifically, by trying to have the immigration judges' union decertified - to effectuate the desired change in public policy. See, e.g., Matt Zapotosky, Justice Department Moves to Potentially Decertify Immigration Judges' Union, WASH. PosT (August 9, 2019), https://perma.cc 14 BQD-77GT. 
private options, the focus of this essay, it is clear that government failures are farranging, consequential, and unlikely to be addressed directly - that is, remedied through constitutional reforms or political awakenings. It is also clear that, for a variety of reasons, powerful firms and groups of employees have the agility, clout, resources, ambition, and possibly civic mindedness to swoop in and (try to) save the day.

Opportunities to create additional or alternative democratic spaces are, to be sure, exciting. But we must be cautious, even watchful. Exercises of private power however much divorced from the logic and lure of profit-maximization - are, after all, still exercises of private power. Indeed, it strikes me that some, if not all, of the private options discussed in this essay raise serious concerns. What normative criteria would allow us to, say, embrace Facebook's currency or Apple's company town? And even if many of us applaud Silicon Valley engineers' resistance to the Trump administration's family separation policy, how would we feel if those same engineers, flexing their libertarian muscles, held up software essential to implementing duly enacted Medicare for All legislation?

But perhaps greater nuance is required. Perhaps, that is, our standards are too high, at least so long as our democratic institutions are subverted, debased, and distorted by such things as plutocracy, obscurantism, and incompetence.

Thus, as tempting as it might be to reject private options out of hand, we must recognize the litany of government failures that create governance gaps - gaps that firms and firm employees are endeavoring to fill. And appreciating that we may be in a world of only second-bests - where we are forced to choose between greedy, unrepresentative firms and captured, clunky government institutions - we may need to temper our expectations and consider whether to (a) embrace public capitalism and work like crazy to democratize market actors and institutions; (b) recommit to legal liberalism and work just as hard to revitalize government actors and institutions; or (c) let things play out, regulate on the margins, and hope the existence of sovereign-commercial competition - a hallmark of public capitalism brings out the best in everyone.

Obviously, much work, normative, legal, and empirical, remains to be done. This essay represents just an initial foray, one that - I hope - spurs further research, debate, and refinement. 